\title{
REPUBLIC OF MACEDONIA AND CONTEMPORARY MIGRANT AND REFUGEE CRISIS
}

\author{
Nikola Dujovski, PhD \\ Faculty of Security \\ E-mail: ndujovski@fb.uklo.edu.mk \\ Snezhana Mojsoska, PhD \\ Faculty of Security \\ E-mail: smojsoska@gmail.com
}

\begin{abstract}
The contemporary refugee crisis brought numerous challenges and raised many questions about the capacity and the ability of Macedonian security system. Two aspects of dealing with this crisis are especially significant: first - to minimize the challenges of the large number of refugees, while respecting the accepted world standards for protection, and second - to protect Macedonia's borders and interests.

The first "wave" of the worst refugee crises in modern society fared relatively well and the security forces of the Republic of Macedonia demonstrated a high level of response capability. Along with the political decisions that aimed to prevent endangering the security of the state and citizens, in terms of introducing a state of emergency and the involvement of several bodies and institutions, were mitigated the consequences that could arise for the system as a whole, but also for the security of citizens in general.

However, monitoring of the current security and political situation in the Middle East, especially in the countries from whence came the largest number of refugees before, leads to the conclusion that it is possible to recurrence the situation from 2015 and 2016. Therefore it is very important to monitor the condition of multiple
\end{abstract}


levels, to propose measures and activities aimed at timely and quality response to future challenges related to any new security threats.

The paper aims to analyze the recent papers in this area, and to offer new horizons to the possible movements of refugees, their origin, objectives and interests and so on. The authors will analyze the statistics on refugee movement, and measures undertaken by the security forces. It could appear as a good basis for planning the future activities.

Key words: refugee, crisis, security forces.

\section{INTRODUCTION}

Migration in the modern world are real, everyday needs, which included a numerous number of countries in the world. Depending on the period of development there were just different ways of migration and reasons why people decide to migrate. In the $20^{\text {th }}$ century we can recognize three general periods of massive migrations of people on the European continent: after World War I, after World War II and in the nineties. In the beginning of the new century, there a lot of new challenges on migration issue. In 2014 starts the biggest migration in the modern history, meaning a millions of migrants' from the Middle East settled in Europe. This paper will focus on this contemporary migrant crisis, with different approach and statistics.

However, almost 20. years ago Massey and his collaborators argued that: The theoretical concepts now employed by social scientists to analyse and explain international migration were forged primarily in the industrial era and reflect its particular economic arrangements, social institutions, technology, demography and politics... The classical approach has now entered a state of crisis, challenged by new ideas, concepts, and hypotheses (Massey, et al. 1998, 3). Although, as they pointed out, 'these new ways of thinking have not yet cohered into a single theory', Massey et al. believed that 'the time has come...to reassess theories of international migration and bring them into conformity with new empirical conditions'. The 'post-industrial, postCold War world' needed a new theory of migration appropriate for 'a brand new century'. (Massey, et al. 1998, 3). In the next two decade, the exponential growth of socialscientific research into international mobility of people shows no sign of abating: we 


\section{Securiatity}

have more researchers, students, research projects, journals and publications than ever before. However, the quest for a generally accepted theoretical framework for migration studies remains elusive. We still lack with to explain why some people become mobile, while most do not, and what this means for the societies where migrants come from, pass through and settle in.

There are some wider accepted definitions on terms related to migrant and migration, but there is no general approach on solving problems and controlling the migrant route. As different type of migration we can recognize (Human Migration Guide 6 $-8,2005$, p. 1):

- Internal Migration: Moving to a new home within a state, country, or continent.

- External Migration: Moving to a new home in a different state, country, or continent.

- Emigration: Leaving one country to move to another (e.g., the Pilgrims emigrated from England).

- Immigration: Moving into a new country (e.g., the Pilgrims immigrated to America).

- Population Transfer: When a government forces a large group of people out of a region, usually based on ethnicity or religion. This is also known as an involuntary or forced migration. (This will be the author exceptional interest, having in mind that most of the migrants coming from Middle East are running away because of the war or conflicts in their own countries).

- Impelled Migration (also called "reluctant" or "imposed" migration): Individuals are not forced out of their country, but leave because of unfavorable situations such as warfare, political problems, or religious persecution.

- Seasonal Migration: The process of moving for a period of time in response to labor or climate conditions (e.g., farm workers following crop harvests or working in cities off-season; "snowbirds" moving to the southern and southwestern United States during winter).

About people who migrate (Human Migration Guide 6 - 8, 2005, p. 2):

- Emigrant: A person who is leaving a country to reside in another.

- Immigrant: A person who is entering a country from another to take up new residence. 


\section{Securiagues}

- Refugee: A person who is residing outside the country of his or her origin due to fear of persecution for reasons of race, religion, nationality, membership in a particular social group, or political opinion.

- Internally Displaced Person (IDP): A person who is forced to leave his or her home region because of unfavorable conditions (political, social, environmental, etc.) but does not cross any boundaries.

- Migration Stream: A group migration from a particular country, region, or city to a certain destination.

People move for a different reasons. Generally speaking there are two factors of migration: Push Factors: Reasons for emigrating (leaving a place) because of a difficulty (such as a food shortage, war, flood, etc.) and Pull Factors: Reasons for immigrating (moving into a place) because of something desirable (such as a nicer climate, better food supply, freedom, etc.). Several types of push and pull factors may influence people in their movements (sometimes at the same time), including:

1. Environmental (e.g., climate, natural disasters)

2. Political (e.g., war)

3. Economic (e.g., work)

4. Cultural (e.g., religious freedom, education)

\section{CONTEMPORARY MIGRATION IN A MODERN WORLD}

The number of international migrants worldwide has continued to grow rapidly over the past fifteen years reaching 244 million in 2015, up from 222 million in 2010 and 173 million in 2000 (UN IMR 2015, 2016.). The increasing numbers are to be taken very seriously and appropriate politics and measures are to be taken. As Castles and others argued the international migration is part of transnational revolution that is reshaping societies and politics around the globe (Castles and others, 2015: 8). The old dichotomy between migrant-sending and migrant-receiving states is being eroded. Most countries experience both emigration and immigration (although one or the other often predominate) while some countries have taken on an important role as transit zones for migrants. The differing ways in which such trends have affected the worlds' regions is a major theme in a contemporary studies and researches. 
As far as globalization provide benefits, also incurring problems faced by many people around the world. The increased standards and low incomes, or relentless wars and terror against people, encouraging those people, who come from war-torn territories to leave their country. Most of the time, they migrate to some of Western European countries, not only to receive asylum, but to begin a "new life". Unfortunately, they are not able to enter EU without visa and other permission, so they use forge canals, walking a thousand of kilometers, often caught in the network of smugglers of migrants. Today's migrations, which mainly consist of nationals from Iraq, Iran, Syria, Afghanistan and others pass through our country, that follow the Balkan route, which includes the Republic of Macedonia. Mainly there are five reasons that encourage people to migrate, as so: ${ }^{77}$

1. The war in Syria, which lasts for five years and there are no hopes to be finished shortly. So far, there were about 250,000 dead people, so the population tends toward migration. Also, a large number of migrants come from Afghanistan, Somalia, Nigeria, and so on, also because of the war or war activities in a certain territories.

2. A second major reason is the cost of transportation. In the past when migrating went mostly through Libya and hence paid ship to reach Italy and the transport cost about $\$ 6,000$. Today it is known that the Balkans route is twice cheaper, or about $\$ 3,000$.

3. One of the leading reasons is the great welcome for refugees from Cermany. Germany suspend the Dublin Regulation, which states that every refugee must seek asylum in this country where they first arrive, delighted Syrians.

4. The recruitment of young forces in Syria, up to 30 years for taking part in the current war is the next leading factor, so a lot of them have decided to migrate in order to avoid mobilization. Contradicting previous said that Syrian government bring a decision that by paying the $\$ 300$ fee, young men could delayed the time for going to the army. And also, they facilitated the way of obtaining a passport.

5. And as a final reason - the International community. Before starting this wave of migration, Syria left around 4 million people and rushed to neighboring countries. However, due to poor conditions in which they live in these

${ }^{7}$ https://www.iom.int/countries/former-yugoslav-republic-macedonia\#fm 
countries, this time refugees choose Europe as an appropriate solution to their problem.

Republic of Macedonia if facing both, emigration and immigration. However, this paper will focus at the most on the contemporary migrant and refugee crisis, having the first wave in 2014-15, but with a high possibility to happen again in the near future. In this context the author agree that Macedonia have taken an important role as a transit country for almost a million migrants passed through the territory of Macedonia in the past two-three years. And not only the Republic of Macedonia, but a lot of other Balkan countries has been so-called "transit countries" on the Balkans route.

\section{REPUBLIC OF MACEDONIA AND CONTEMPORARY REFUGEE CRISIS}

Since 2014, the Republic of Macedonia is facing the greatest challenges in the modern history - a contemporary migrant and refugee crisis. More than a million people from the Middle East (most of them citizens of Syria and Iraq, but also from Afghanistan, Pakistan and some African countries), passed through the territory of Macedonia on their road to EU (especially Western European countries). The new situation implies two different approaches. On one hand, the humanitarian aspect, and on the other hand security implications. Republic of Macedonia has signed up a numerous international conventions and resolutions on migrant and refugee protection, where the obligations of each particular country are foreseen, when facing international issues related to migrants and refugees. Therefore, Macedonia is obliged to act in human way, respecting at the higher possible level all human rights of migrants and refugees. The refugee crisis consisted of persons who have fled of war, which is generally caused by violence at their own countries. According to EU Directive No. $2004 / 83 / \mathrm{EC}^{78}$, those individuals have the right of protection, so-called subsidiary protection. The county give the best possible way to respect international and domestic

78 European Union's minimum standards definition of refugee, underlined by Art. 2 (c) of Directive No. 2004/83/EC, essentially reproduces the narrow definition of refugee offered by the UN 1951 Convention; nevertheless, by virtue of articles 2 (e) and 15 of the same Directive, persons who have fled a war-caused generalized violence are, at certain conditions, eligible for a complementary form of protection, called subsidiary protection. 
standards, but we must have in mind that Macedonia is a small and vulnerable country with limited resources and capacity to answer all needs of migrants and refugees. On the other hand, Macedonian Police and Army give their best efforts to protect our borders and to prevent uncontrolled movements of large groups of migrants. The purpose of the migrants was not to stay in Macedonia, but on a fastest way to reach some of the EU countries (most in Germany, Belgium, Sweden, later Austria and others). As a matter of fact, there were a lot of challenges for Macedonian people, their personal safety and especially protection of the property. However, there were no serious violations of international standards, and there were no serious threats of domestic security.

We could say that this is the main problem that Europe has faced in the 21st century, and that definitely this refugee crisis will have consequences, both for Macedonia and Europe in the coming years. That is why, the elaboration of this theme is necessary and appropriate. The authors will present official data, collected by the official state agencies responsible to answer the refugee crisis challenges, and will address different aspects of Macedonian occasions when solving this issue.

The so-called "refugee crisis" in the Republic of Macedonia began in 2014, but has taken serious numbers in the mid-August of 2015, when a number of 53000 people come to Greek-Macedonian border in the period of two-three weeks. After this new situation, on $19^{\text {th }}$ August 2015, the Government declare a crisis on Southern and Northern Borders. ${ }^{79}$ According to the legislation, this decision opens the possibility for proper engagement of the Army of the Republic of Macedonia. linter-institutional coordination body daily monitors the illegal migrants who intend to enter the territory of the Republic of Macedonia from Greece and establish appropriate response analyzes all possible scenarios. Because of increased pressure on the southern border and the growing intensity of transit through etc. Balkan migration corridor, but the situation in global terms, it was estimated that it is necessary further increased and more effective control of the border areas where there have been mass illegal crossings from Greece. The involvement of the Army has an outcome in two directions. First, to increase the security and tranquility of the local population and second, to ensure a more comprehensive approach to the treatment of persons who have expressed their intention to seek asylum in the country according to the capacity and the

${ }^{79}$ http://vlada.mk/node/10918 
recommendations of the conventions whose signatory is the Republic of Macedonia. Just after declaring the crisis, within the Crisis Management Centre, a Headquarter was establish, with the main task to monitor and follow the situation and to prepare an action plan and to implement the planned activities. Headquarters of the Center for Crisis Management is an operational expert body which manages the activities of prevention and management of crisis situations and is composed of representatives of the following ministries: interior, health, transport and communications, defense and foreign affairs. Its members include the head of emergency medical assistance in Skopje, the Director of the Directorate for Protection and Rescue, as well as representatives of the Army, Intelligence Agency, the Directorate for Security of Classified Information and the Red Cross of Macedonia.

The statistics for 2015 are different and depend of the source used. However, the precise number is impossible to count. The institutions has a different approach and begin fully control in the middle of the crisis. According to the official statistics of the Ministry of Interior, the number are as follows: 


\section{Seccurity}

Table 1. Number of refugees in the Southern border of the Republic of Macedonia in $2015^{80}$

\begin{tabular}{|l|l|l|l|l|}
\hline $\begin{array}{l}\text { Indicators / } \\
\text { Month }\end{array}$ & $\begin{array}{l}\text { Illegal crossing of } \\
\text { the National border }\end{array}$ & $\begin{array}{l}\text { Foreign nationals who } \\
\text { have been refused for } \\
\text { entry }\end{array}$ & $\begin{array}{l}\text { Asylum } \\
\text { seekers }\end{array}$ & $\begin{array}{l}\text { Children } \\
\text { parental } \\
\text { accompaniment }\end{array}$ \\
\hline January & 282 & 323 & 201 & 750 \\
\hline February & 199 & 355 & 138 & 808 \\
\hline March & 166 & 353 & 141 & 785 \\
\hline April & 284 & 389 & 112 & 547 \\
\hline May & 318 & 325 & 175 & 746 \\
\hline June & 16.021 & 319 & 671 & 1.043 \\
\hline July & 57.367 & 505 & 229 & 2.577 \\
\hline August & 171.066 & 414 & 15 & 6.976 \\
\hline September & 171.422 & 368 & 20 & 6.118 \\
\hline October & 191.589 & 491 & 29 & 4.150 \\
\hline November & 144.273 & 354 & 41 & 2.377 \\
\hline December & 101.843 & 346 & 116 & 1.077 \\
\hline $\begin{array}{l}\text { Total in } \\
\text { 2015: }\end{array}$ & 854.830 & 4.542 & 1.888 & 27.954 \\
\hline
\end{tabular}

To facilitate the movement of migrants across the territory of the Republic of Macedonia, the Parliament adopted amendments to the Law on Asylum. Macedonia changed its asylum law on 18 June 2015 to let migrants entering the country illegally avoid jail if they leave within three days. The move follows a series of fatal accidents involving migrants traveling through Macedonia on the way to more prosperous European countries, following dangerous routes to avoid police arrest. It allows migrants to apply for temporary asylum at the border or the nearest police station. That will allow them to travel legally through the country for three days. ${ }^{81}$ The new Law

\footnotetext{
${ }^{80}$ http://moi.gov.mk/analiza/granichni-premini/2015

${ }^{81}$ http://www.voanews.com/a/macedonia-migrants-asylum-law/2828577.html
} 


\section{Securiagues}

Amending the Law on Asylum ${ }^{82}$ make a distinction between the intention to submit a request for recognition of right of asylum and the formal aspect, ie the request for recognition of the right of asylum, by potential asylum seekers.

Undeniable is the human aspect of this law, which has contributed significantly to improve the mobility of migrants from the southern to the northern border of the country. However, the figures presented in Table 1 are extremely serious and worrying. With a look at the last column, one may note that in 2015 in Macedonia come 27954 children without parental care. $10 \mathrm{M}$ and other international organization take care about all of them (at least temporary protection). Less than 1000 children were connected with their families. Others were send to Serbian authorities for further proceedings. IOM has followed them through the final destination. ${ }^{83}$

The first wave of migrant crisis passed without serious consequences for the country. Financial costs were quite high, and the assistance of the relevant European and international institutions lacking. It is not immodest to say that the state was left to itself to cope with the wave of migrants which were about $50 \%$ of the total population. At a later stage of dealing with the migrant crisis, several EU countries ${ }^{84}$ sent police officers in Macedonia. Their activities were more declarative than actually helping in controlling and dealing with the influx of people on Macedonian borders. The good side of dealing with the crisis is recognized in fact that the authorities has learned good lessons. Capacities of the Police and Macedonian Army shown as appropriate and with enough skills and knowledge to deal with eventual upcoming crisis.

\section{CURRENT SITUTATION OR WHAT WE CAN EXPECT}

According to the last reports, number of migrants especially on Greek island is increasing. Since the EU signed a deal with Turkey to halt the influx, the numbers have dropped dramatically but there are fears the reduction may not be sustainable. And because of new rules that prevent irregular migrants crossing to the Greek mainland,

\footnotetext{
${ }^{82}$ Article 16a of the Law Amending the Law on Asylum, Official Gazette of the Republic of Macedonia nr. 145, June 2015

${ }^{83}$ http://publications.iom.int/system/files/wmr2015_en.pdf, p. 133

84 Including Austria, Hungary, Slovenia, Slovakia and later Croatia.
} 


\section{Seccurity}

record numbers have become stuck in increasing squalid conditions, and are becoming more angry and desperate, says the UK-based charity. More than 10,000 migrants are currently being held on islands of Lesbos, Chios and Samos - the bulk of whom are fleeing violence and poverty in Syria, Afghanistan and Iraq. ${ }^{85}$

Europe's migrant crisis in numbers: ${ }^{86}$

- Over 275,000 migrants have reached Europe in 2016.

- All but 10,000 have come by sea

- 161,599 have arrived in Greece

- 101,485 have reached Italy from North Africa

Following the situation in Turkey, the one may conclude that controlling and dealing with migrants is not going to be a high priority of Turkish Authorities. As the spring is coming we may witness a new migrant crisis on our borders. The summer months routinely see a rise in the number of migrants attempting to reach Europe as they take advantage of better weather conditions to make the arduous journey. Concern among European politicians is obvious, and visits that happen during January and February 2017, among other aim was to assure that Macedonia continues to be a credible partner in dealing with migrants. Although the Balkan route was declarative closed almost every day the official's record number of new migrants who cross the territory of the Republic of Macedonia. An average of 200 migrants per day arrive at the southern border, or about 2,500 in a month. After this, they are using different ways and channels to reach the EU.

One might say that Greece is taking serious measures to prevent new strong wave of migrants and supported by the EU to reduce the suffering of people arriving mainly from Turkey. Greek Coordination Centre for Management of the Migrant Crisis declare 64832 beds of total capacity, and at the moment there are 33783 people cared for ${ }^{87}$ The very new situation in Greece is as follows: ${ }^{88}$

- Total arrivals in Greece (Jan - Feb 2017): 1,864

- Total arrivals in Greece during Feb 2017: 471

- Average daily arrivals during Feb 2017: 39

\footnotetext{
${ }^{85}$ http://www.bbc.com/news/world-europe-37099332

${ }^{86} \mathrm{https}$ // www.iom.int/news/iom-Europe's-migrant-crisis-in-numbers

${ }^{87}$ file:///C:/Users/user-pc/Downloads/GreeceSites20170214.pdf

${ }^{88}$ file:///C:/Users/user-pc/Downloads/Daily_Arrival_Greece_20170212.pdf
} 


\section{Seccuritity}

- Average daily arrivals during Jan 2017: 45

- Daily estimated departures from islands to Mainland: 13

- $\quad$ Estimated departures from islands to Mainland during Feb 2017: 778

The route of migrants are well known. They are using Turkey, Greece, Macedonia (or Bulgaria), Serbia, Croatia, Slovenia, Austria to reach Germany at the most. The picture below shows the Balkans route. In the beginning of the crisis they used Hungary instead of Croatia and Slovenia, but Hungary has built up a wall in order to stop the migrants on Serbian borders.

Picture 1. Migrant route to Germany through Balkans route ${ }^{89}$

\section{Migrant route to Germany}

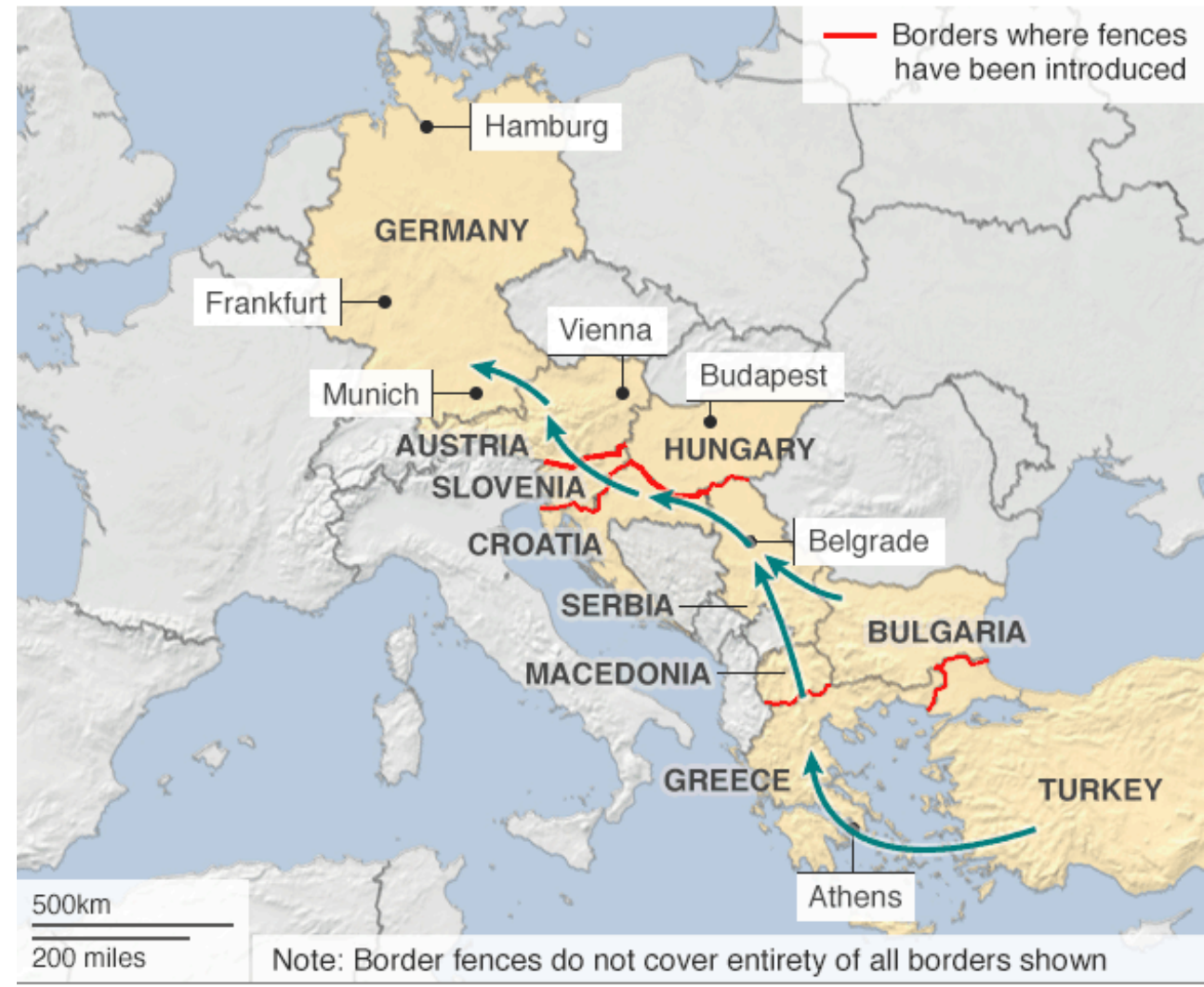

Source: UNHCR

${ }^{89}$ UNHCR, published on http://www.bbc.com/news/world-europe-37099332 
As the spring is coming we can expect those number to increase. The main reason is that the war in Syria is not ending, and the situation in Middle East is not getting better. That's why, the Macedonian authorities should monitor the situation on a daily basis, to prevent any escalation, to protect our borders and to secure people and their properties.

\section{CONCLUSSION}

Past two years were extremely challenging. It was a very new experience for Macedonian Police and Army, as well as for all other institutions and agencies to deal with almost one million migrants in a period of less than a year. In the very beginning, we were unable to deal on an appropriate way, so we were witnesses of a numerous accidents involving migrants. In this manner, the author is emphasizing that migrants are often a victims of crime. Trafficking in Human Beings is another challenge for the Police and they should be aware of importance and meaning of this global phenomenon. More than 35 people were killed on Macedonian railways, a lot of them were fallen into the network of smuggling migrants. 30 criminal charges for total number of 42 Macedonian citizens were brought for smuggling in the first half of 2015.

However, migration flows, in particular when inadequately managed, can actually result into conditions of exclusion and vulnerability for those moving, as well as for their host communities. Migrants often face specific barriers and obstacles that result in specific patterns of marginalization. Even that Macedonian is not in their interest, all of us should be aware that they could be a potential challenge. As a consequence, Macedonia must follow what will happen in the near future, to monitor the situation especially what happening in the Greek islands and how the implementation of EU - Turkey agreement goes. Lessons learned from the previous situation and crisis management are good experience and possible solutions for upcoming events regarding migrants and refugee crisis.

The authors recognize that Macedonian authorities give their best to manage the crisis from 2015. The impact of the refugee crisis is important. Macedonia has faced numerous challenges: the protection of national interests and security; responsible and humane treatment of refugees (limited facilities for reception, insufficient support from the EU and international organizations). While the "Balkan Route" was opened, most of 
the refugees spand less than 72 hours and relatively safely passed the way from the southern to the northern border. A particular problem caused the closure of the "Balkan route" when at the southern border remained "stuck" thousands of refugees. The fact that they came on our borders from EU Member State additionally has complicated the dealing with their pressure to enter the country. First serious problems happened in that time. The Police was forced to use force and other powers. Considering the possibility of new refugee wave, it is necessary to take a number of actions that will lead to better preparation of services:

- Especially useful would be educational seminars for police officers and soldiers.

- The enhancement of international cooperation, especially cooperation between neighboring countries - Greece - Macedonia - Serbia.

- To exchange experiences with countries that have faced or are facing migrant crisis.

- $\quad$ IOM and UNHCR to engage with more resources (material and human).

- In addition to the already installed wire fence, the authorities to provide border control with thermal cameras and motion sensors.

- To pursue continuous follow-up, to prepare analyzes on a daily and monthly basis, to increase the capacity for stay and accommodation.

\section{LITERATURE}

1. Castles, Stephen, de Haas Hein and Miller, J. Mark. (2015).The age of migration. London: Palgrave Macmillan Higher Education.

2. Дујовски, Никола (2009) Шенген и потоа. Кочани: УНИ-Конзум;

3. European Commission, Official Journal of the European Union (2004) EU Directive No. 2004/83/EC on minimum standards for the qualification and status of third country nationals or stateless persons as refugees or as persons who otherwise need international protection and the content of the protection granted. Luxemburg: Office of Publication.

4. Law Amending the Law on Asylum, Official Gazette of the Republic of Macedonia nr. 145, June 2015; 
5. Massey, D., S., Arango, J., Hugo, G., Kouaouci, A., Pellegrino, A. and Taylor, J. E. (1998) Worlds in Motion, Understanding International Migration at the End of the Millenium, Oxford: Clarendon Press.

6. Николоски, Златко (2010) Миграции- контраиндикации или причина за позитивни ефекти. Скопје: Уни Графика

7. Public Prosecutor Office (2015). Annual Report for 2015. Crimes against Humanity and International Law (article 403 - 422).

8. United Nations, Department of Economic and Social Affairs, Population Division (2016). International Migration Report 2015: Highlights (ST/ESA/SER.A/375).

\section{INTERNET SOURCES}

1. International Organization for Migration (2016). Facilitating Migration. Office in Skopje, Macedonia. https://www.iom.int/countries/former-yugoslav-republicmacedonia\#fm (visited on 11.2.2017)

2. International Organization for Migration (2016). World migration report 2015. http://publications.iom.int/system/files/wmr2015 en.pdf ISBN 978-92-9068709-2 ISSN 1561-5502 (visited 11.2.2017)

3. International Organization for Migration (2016). Europe's migrant crisis in numbers. https://www.iom.int/news/iom-Europe's-migrant-crisis-in-numbers (visited on 14.2.2017)

4. Macedonian Asylum Law. Changes in 2015 (2015). http://www.voanews.com/a/macedonia-migrants-asylum-law/2828577.html (Visited on 11.2.2017)

5. Migrant route to Germany (2016). http://www.bbc.com/news/world-europe$\underline{37099332}$ (visited on 15.2.2017)

6. Ministry of Interior. Total number of refugees in 2015 (2015). http://moi.gov.mk/analiza/granichni-premini/2015 (visited 11.2.2017)

7. National Geographic Expedition, Marko Polo Edition. (2005). "Human Migration Guide 6 - 8"

www.nationalgeographic.com/xpeditions (visited on 29.1.2017).

8. Number of migrants in August 2016. BBC Report (2016). http://www.bbc.com/news/world-europe-37099332 (visited 14.2.2017) 
9. The Government declare a crisis situation. (2015) http://vlada.mk/node/10918 (visited on 3.2.2017)

10. UNHCR. Europe Refugee Emergency (2017). Daily map indicating capacity and occupancy (Governmental figures) As of 14 February 2017 08:00 a.m. EET. file:///C:/Users/user-pc/Downloads/GreeceSites20170214.pdf (visited 15.2.2017)

11. UNHCR. Greece data snapshot (2017). New arrivals in Greece as of 12 February. file:///C:/Users/user-pc/Downloads/Daily Arrival Greece 20170212.pdf (visited 15.2.2017) 